\title{
Russia's curtained window on the west
}

In the 250th anniversary year of the Russian Academy of Sciences. Vera Rich examines the rôle the Academy has played in international science.

Ir can hardly be doubted that, in founding his Imperial Academy of Sciences, Peter the Great intended it to form one of the cornerstones of his Westernising policy-a consummation at the highest intellectual level of the European outlook that had driven him, earlier in his reign, to cut off his subjects' beards and to impose the death penalty on courtiers found sleeping with their boots on.

Yet Peter, who was personally curious about all branches of science and technology from the theory of navigation to do-it-yourself dentistry, having, after more than 20 years' cogitation, finally signed the decree "establishing" the Academy, on January 28, 1764, did not live to attend its opening. Exactly a year later, he died, succumbing to a chill caught, not in the pursuit of his innovations, but as a result of attending the traditional Epiphany Eve blessing of the waters! It was left to his widow and successor, the erstwhile illiterate Livonian peasant-girl, who reigned as Catherine $I$, to bring into being Peter's Academy, and it was on her nameday, December 27, 1725, that the inaugural meeting was held.

Although he is reputed never to have opened a book (and it must be said in passing that the improbably tall stories surrounding his name are more than legion), Peter seems to have been giving serious thought to the foundation of some eminent scientific body to grace his projected new capital and "window on the west" as early as the 1690s. During his visit to England in 1698, he visited the Royal Society (January 27), Greenwich Observatory (March 9) and Oxford (April 8) where he was presented with a number of mathematical books.

Back in Russia, he founded a Naval Academy, Artillery, Engineering and Medical Schools, and Russia's first national museum, the Kunstkamera, in his new capital of St Petersburg, together with several printing presses using the simplified typography, which he had introduced in 1708. He also began a prolonged correspondence with Leibniz, who had organised the Berlin Academy of Sciences in 1700 , on the possibility of establishing a similar

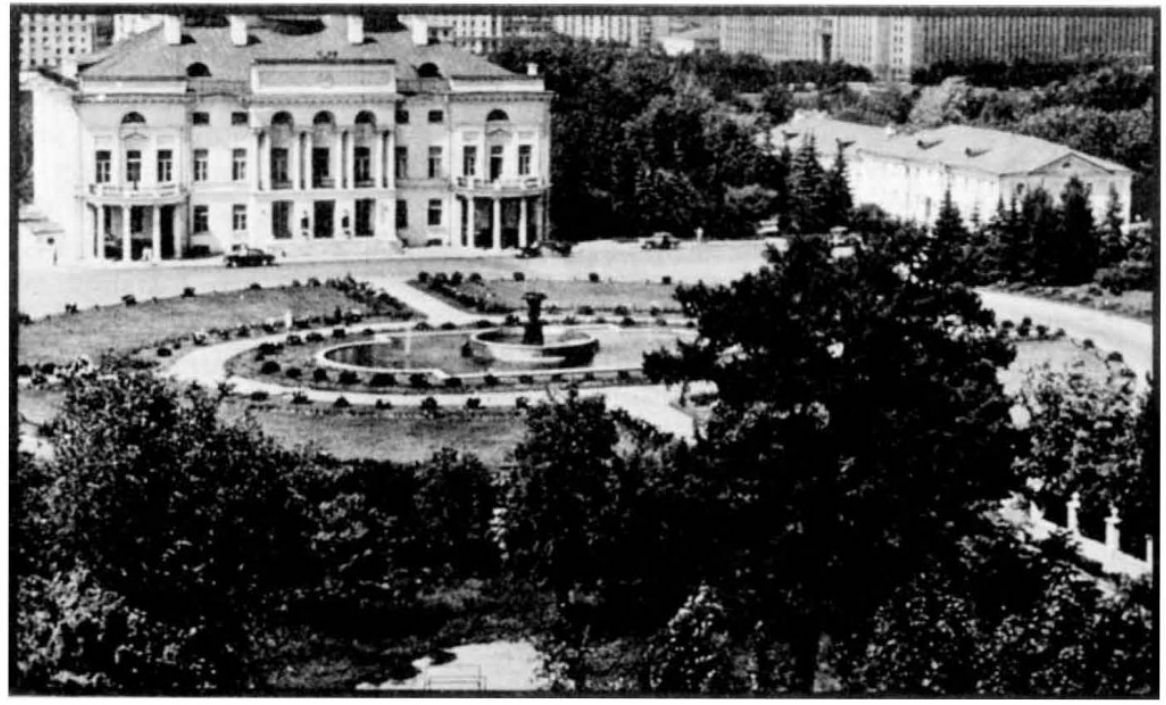

institution in St Petersburg. Although neither Peter nor Leibniz were to see the Academy come to fruition, nevertheless, in 1725 the first meeting finally occurred, and with a membership mainly of foreign, especially German savants.

This foreign, or rather, international, membership, persisted through the first difficult years of the Academy's existence (it had no official constitution until 1747, nor any established source of income). Prominent Academicians of that time include such eminent names as Nicholas (II) and Daniel Bernouilli (elected 1725), Leonard Euler (1727) and Georg Wilhelm Steller (of 'seacow' fame) (1737). It was from Euler's time at the Academy that the famous problem of the 'seven bridges'-one of the early landmarks of topology-dates. In spite of this source of inspiration, Euler found the atmosphere of St Petersburg unconducive to the free exchange of ideas, and in 1741 he accepted an invitation from Frederick the Great to join the Berlin Academy. (Asked by the Dowager Queen why he could only, apparently, speak in monosyllables, Euler is reported to have replied that "I've just come from a country where, if you speak, you're hanged!") In 1785, however, on the invitation of Catherine II, Euler returned to St Petersburg, where, in the intervals of research, he was expected to produce such diversions for the court as a formal mathematical refutation of the 'atheistic' views of the visiting French philosopher Diderot. (Euler's tongue-in-cheek "proof": "Sir, $\left(a+b^{n}\right) / n=x$, hence God exists;
The Academy's Moscow headquarters.

reply!", astounded the court, discomfited the unmathematical Diderotand is reported to have found a place in current theological treatise!)

In spite of such Imperial digressions, the Academy at last settled down to producing its own scientists and scholars. Among numerous lesser luminaries, one finds names such as Lomonosov (elected 1741), Lenz (1828), Ostrogradskii (1828) and Krylov (of the Fables (1841).

There was still, however, a strong international atmosphere, reflected specially in the honorary members, who included Réaumur (1737), Voltaire (1778), Linné (1754), Boscovitch (1759), d'Alembert (1764), Diderot (a reward, maybe for valour?) (1773), Lagrange (1776), Bode (1794) and Kant (1794). British honorary members included such well-known figures as Maskelyne (1776), Priestley (1780), Sir Joseph Banks (1780), Malthus (1826), Sir William Parry (1826), Sir Humphrey Davy (1826) and Faraday (1830). In the eighteenth century, the United States was represented by honorary members Benjamin Franklin (1789) and John Churchman of Philadelphia (1795).

Yet in spite of its international beginnings, its use of Latin, French or German as its medium of publication (the Comptes Rendus of the Academy was still appearing in French in the 1940s), and the continuing election of foreign scientists as honorary members, the international contacts of the Academy did not proceed smoothly and unbrokenly. The early years of the nine- 
Peter the Great: intended the Academy to form one of the cornerstones of his Westernising policy-a consummation at the highest intellectual level of the

European outlook that had driven him to cut off his subjects' beards and to impose the death penalty on courtiers found sleeping with their boots on.

teenth century showed the Academy fallen on hard times. This was partly as a result of the foundation of new universities, so that the Academy lost a certain amount of prestige, being no longer the ions et origo of all learning in Russia, partly this was due to the conditions of the Napoleonic wars. Further, under Paul I (1796-1801), the receipt of literature from abroad was forbidden and international contacts were broken off. The membership of the Academy was reduced to half its original strength-and a large proportion of the remaining members were superannuated veterans, no longer able to attend meetings!

Paul's successor, Alexander I, was keenly interested in education, founding Universities (or reconstituting those, Vilna and Dorpat, which he had gained in recent territorial acquisitions). But although the Academy gradually regained its old strength and vigour, the vexed question of censorship remained. Knowledge might, and did, flow out of Russia-it was considerably more difficult for it to flow, or even to trickle in. The nineteenth century witnessed a running battle between the Academy and Universities on the one hand and the Government on the other, on the right of learned bodies to import foreign literature, especially periodical literature, without inspection by the censors. (It should be noted that censorship was, at times, ludicrously rigid; on one notable occasion a mathematical treatise was refused publication since it was feared that the "..." of the formulae for infinite series denoted a lacuna into which some revolutionary or otherwise treasonable matter would be inserted by dissident minds.) Although from the beginning, the Academy and Universities had been able to import scientific works (indeed, without them, no learned institution would have ever been able to begin functioning), the dispute arose out of the definition of "scientific". The new constitution of Vilna University (1803) implies that the Universities are to censor themselves. The decree on censorship of 1828 permitted the Universities and the Academy to "receive books without inspection by the censorship", but they are obliged "every time to inform the censorship committee for foreign books what the books are, how many, and when and by what route they were sent".

Although even the natural sciences (with their suspect symbolism) were not

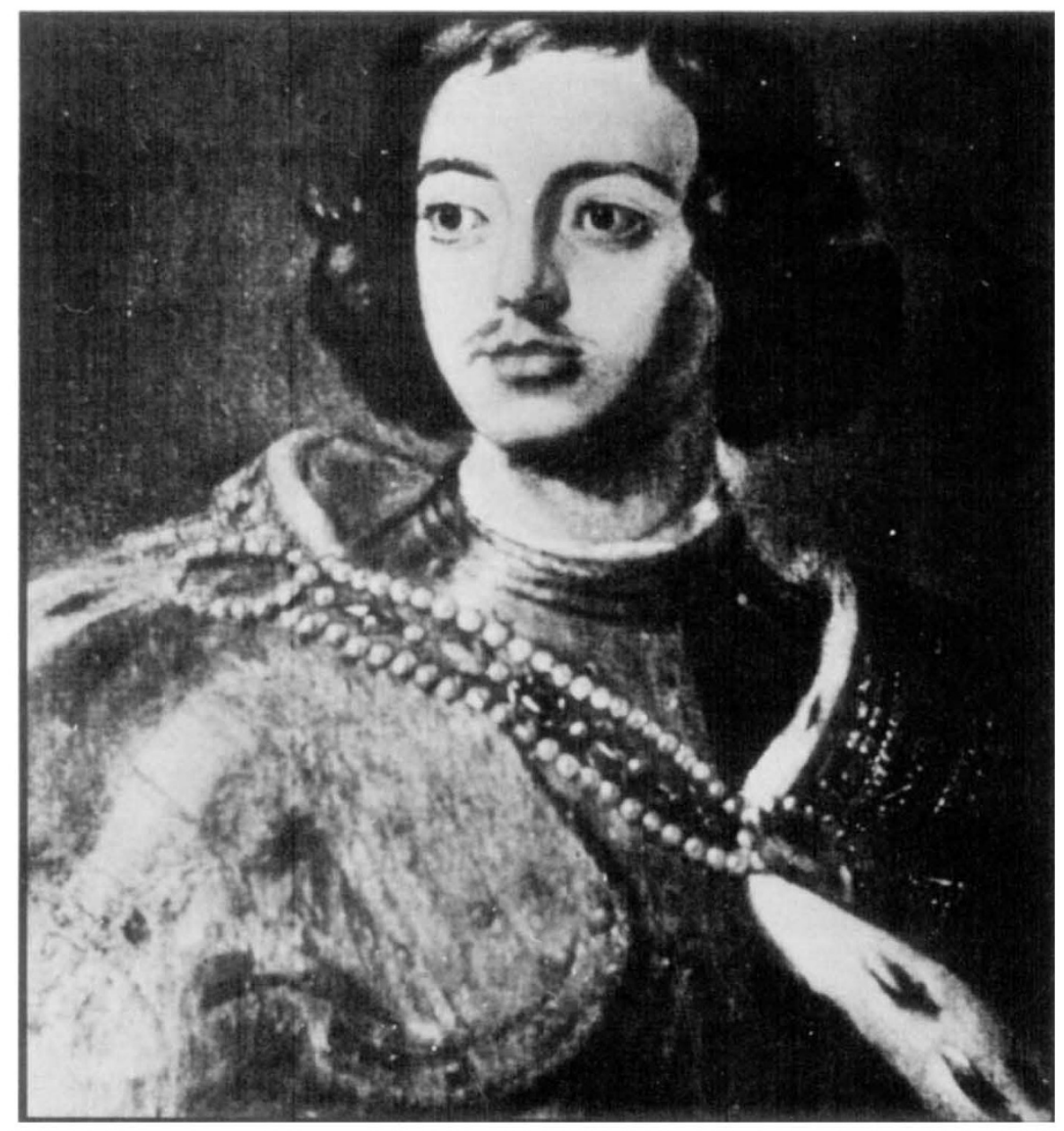

exempt from import difficulties, the problem was particularly pressing with the 'philosophers', who needed to read current political journals. The restrictions seem to have been imposed somewhat intermittently, according to the prevailing political atmosphere. Thus in the 1840 s for example, the Academy was able to receive the Allgemeine Zeitung and Berliner Nachrichten fairly freely. A decree of 1860, however, imposes somewhat narrow limitations: "The Imperial Academy of Sciences, the Pulkova Observatory and the Universities may enjoy the right to obtain through the post from abroad books and periodical literature of academic content in an open wrapper, without extension of this right to members of the Academy and Universities." And since the opinion of the censorship on what was, and was not academic, was extremely arbitrary, one may find in these restrictions at least a partial explanation of the many claims that Russian scientists have discovered or elaborated some principle "independently" of work done abroad. Although most of the more fantastic claims disappeared with the excesses of the personality cult, one still finds from time to time references, for example, Pravda, June 12, 1973, to Popov as the inventor of radio. Such parallelism may be attributable, at least in part, to these censorship difficulties - a Russian working in a given field might well have been completely unaware of what his opposite numbers abroad were doing. Yet, conversely, certain eminent nineteenth century Russian scholars were never to become Academicians, Lobachevskii spent his life in the backwater of Kazan' and Mendeleev was refused membership on account of his dangerously 'liberal' views. One way and another, the nineteenth century Academy lost much by governmental intervention.

From the leisured days of the beginnings of the Academy (one eighteenth century silhouette shows an open air meeting reminiscent of a fête champêtre rather than a learned discourse) to the earnest days of post-Revolutionary Petrograd seems a far cry, yet, according to an official report of 1927 , one of the first thing that the new régime did was to restore the old international contacts. "In the last ten years, the international relations of the Academy have taken the following forms: (1) participation of the Academy in permanent international unions and associations of general scientific interest or of special disciplines; (2) joint scientific enterprises, such as expeditions, publications, etc.; (3) participation of the Academy in International and other meetings and congresses convened 
abroad, and in the anniversaries of learned societies, scientific institutions or individual scholars; (4) scientific missions abroad, including the permanent work of our scholars in laboratories of other countries; (5) rational and consistent exchange of scientific publications; (6) exchange of collections and the dispatch abroad, on a basis of reciprocity, of collections, manuscripts, and rare editions; (7) awarding of prizes and honorary titles to foreign scholars and mutual invitations to lecture at higher education institutions or to take part in conferences on particular occasions and, finally, rational organisation of the acquisition abroad of publications, instruments, apparatus and all other scientific material, necessary for the Academy and its institutions".

To what extent this excellent programme was implemented it is difficult to judge-official reports of this kind always have a tendency to overstate achievements. In any case, the picture was due to change. With the Stalinist purges of the $1930 \mathrm{~s}$, all contact with the West became not only discouragedthey were positively dangerous for those involved. Scientists who had trained abroad (under the plans so recently praised), were particularly vulnerable. In the Academies of the Union Republics (now virtually satellites of the All-Union Academy) where the accusation of 'nationalism' or 'separatism' was always possible, the situation was particularly tense. The $\mathrm{Kiev}$ Academy, for example, had no less than 13 Secretaries between 1921 and 1938, all of whom were, in turn, arrested. The election of foreign honorary members and corresponding members to the Academy came to a sudden halt. In the immediate postrevolutionary period, no foreign members were elected: then one member was elected in 1922, 18 in 1924 (including Frederick Soddy), one in 1925, one in 1926 , five in 1927 , four in 1928 , nine in 1929, three in 1930, two in 1931, six in 1932 , one in 1933, and in 1934, the year in which the Academy formally moved its headquarters (with 250 wagonloads of equipment and more than 300 scientists) to Moscow, time was still found to elect five new foreign members (of whom Max Born was one).

Then comes a complete gap. No further foreign honorary members or corresponding members were elected until 1942, when five new names (including J. B. S. Haldane) appear in the records, presumably as a symbol of Soviet friendship towards the Allies.

As for the work produced by the Academy during the $1930 \mathrm{~s}$, in spite of the new site, increased subsidies, the foundation of new institutes, and all other material government help that a learned institution might well desire,. the growth of what was later to be known as the 'personality cult', was not conducive to sustained and concentrated research. As Robert Conquest has observed, although the man in the street could, in conditions of peril, stop talking, the professors and academicians had to go on lecturing! With the constant attrition due to the disappearance of those whose views failed to coincide with the current official line, and the occasional endorsement of a new theory from Party headquarters, Soviet science was not noted for the free dissemination of ideas. It became inward-looking, and self-congratulatory. When the 220th anniversary of the Academy was celebrated in 1945 (the 'Catherine' date being chosen, since on the 'Peter' date, the Soviet Union was fully involved with her war effort) we find in the proceedings of the occasion that the history of science has been considerably revised!

In aerodynamics, Mendeleev anticipated Prandtl's views on hydrodynamic friction by some 30 years, and a certain Rykachev in 1871 forestalled Eiffel's experiments on the lift of an airscrew by 40 years. The Danish Bering was no longer the discoverer of the Strait which bears his name-he merely confirmed the the discovery made by "the Cossack Deinev" in 1648. The forces of "chemical constitution" (the nature of the chemical bond) were investigated by Butlerov in 1862-although it is somewhat naively observed that as with many other Russian scientists, "his work was not always duly appreciated abroad!"

In the $1950 \mathrm{~s}$ the Academy made a determined effort to free itself from the tight controls which demanded an immediate economic outcome of all projects, and, in spite of conventional lip-service to successive five-year plans, does manage to achieve a considerable

Charter of the Academy.

\section{PRAEFATIO.}

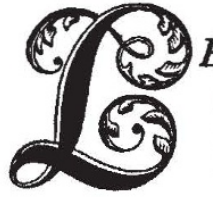

Eges, quibus Academiam fuam $A V$. $G V S T A$ P ROTECTRIX regit, inter cetera falutariter fatuta, etiamidofficii Academicis injungunt, ut, pro excolendis communi confilio E' cura fcientiis, bina fingulis bebdomadis vice omnes conveniant; alteri, ut five deftinationes, five commentationes fuas Sociorum judiciis exponant; alteri, ut communicatis invicem fententiis,$\sqrt{2}$ quid de argumento difquifitioni expofitoutile vel amount of basic research that has little immediate connection with the needs of the economy.

On the international scene, however, all is not entirely well. International co-operation does take place -but with an increased emphasis on co-operation within the Comecon block or on aid to the developing science of the third world. Specific agreements for co-operation between the Soviet Union and a specific Western country on a specific project or set of projects only underline the lack of a general atmosphere of free exchange. Soviet scientific journals flow out freely to the West (and agreements have been made for the production abroad of cover-to-cover translations which appear within a few months of the Russian originals). But western journals entering the Soviet Union do so in single copies, which are then photocopied and distributed to academic institutions with any doubtful matter replaced by backmaterial of a more innocuous nature (for example, advertisements). The campaign of September 1973 against Academician Sakharov stated that "To be a Soviet scientist means to be a patriot"-one must not bite the Party hand that subsidises one's research, by advocating too close a co-operation with the west. The position of Jewish scientists who wish to emigrate to Israel who are refused a visa to emigrate, but at the same time dismissed from their posts so that they can no longer exercise the talents which the state is supposedly conserving for its own use has raised new and bitter feelings abroad.

The inaugural address of 1725 spoke of bringing Russia into the world scientific community. But, no reference was made to the fact that the Royal Society, so admired by Peter, specifically excluded all considerations of the religious or political views of its members-nor, would it seem, has the Academy yet learned, in the 250 years of its existence, to view a scholar's scientific achievements apart from his personal philosophy. The cancellation of the international celebrations of the anniversary of the Academy, and its replacements by a programme of popular scientific lectures to the grassroots of Soviet Society-the workers and peasants, is more, therefore, than a gesture of pique over recent criticisms abroad of the restrictions and lack of academic freedom imposed on certain intellectuals in the Soviet Union-rather is it a repetition once more, of a pattern of isolationism which runs through the history of the Academy, a firm closing, yet again, of what was to have been one of the most prominent casements of Peter's "window on the west". 